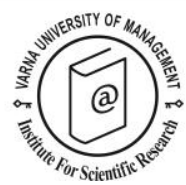

\title{
Dark tourism and memorial tourism: Nexus and divergences between theoretical models
}

\author{
David González Vázquez ${ }^{1 *}$
}

Received: 06/11/2017 Accepted: 11/06/2018

\begin{abstract}
${ }^{1}$ Assistant lecturer at the Faculty of Education at the University of Barcelona, Department of Applied Didactics and fellow member of the Research Group on Didactics of Heritage; Project manager at the European Observatory on Memories (EUROM)- University of Barcelona's Solidary Foundation

Address: Passeig de la Vall d'Hebron, 171. Universitat de Barcelona. Facultat d'Educació. Edifici Llevant, despatx 120. Barcelona, Spain. Email: david.gonzalez@ub.edu

* Corresponding author
\end{abstract}

\section{Abstract}

In the context of the huge diversification in the field of cultural heritage, there are nowadays many touristic places whose main appeal lies in the connection with tragic events. Beyond the scope of cultural tourism, it may be confusing to classify them due to the extraordinary richness and heterogeneity of the different types of tourism as typified by tourism science. Thus, the scientific community uses several labels to name the tourism practices carried out in touristic places linked to tragedy. Among the many, it is worth pointing out dark tourism and memorial tourism, not only because of their undeniable academic impact, but also because of the media relevance gained. This article deals with the problems faced when it comes to determining the boundaries of what may be considered dark tourism or memorial tourism. After a comprehensive analysis of the theoretical contributions regarding both models, what is most relevant is why and in which contexts one term or the other is used.

(C) 2018 Varna University of Management. All rights reserved

Keywords: Dark tourism, thanatourism, memorial tourism, memorial heritage, dissonant heritage

Citation: González, D. (2018) Dark tourism and memorial tourism: Nexus and divergences between theoretical models. European Journal of Tourism Research 20, pp. 46-58

\section{Introduction}

The field of tourism studies has in recent decades been the protagonist of an important cultivation that places it at a prestigious academic level, a constant stream of new, multidisciplinary contributions that help us understand the phenomenon of tourism from a variety of complementary perspectives. Today, tourism science is extremely fruitful when it comes to providing new theoretical notes that contribute to the classification and cataloging of emerging forms of tourism.

Arising from the evolution and diversification of cultural heritage, we find emerging tourist types of almost infinite quantity within the vast branch 
of cultural tourism (González, 2017). The 20th century, so fertile in social, cultural and technological advances resulted, however, with the development of new military techniques which brought with it the most catastrophic war conflicts in the history of mankind. Consequently, many new instances of repression associated with extreme ideologies have irreparably damaged many countries scattered around the world. This has meant that there is now an immense history of heritage related to these aforementioned events (Guixé, 2017). They are the proverbial fingerprints of the horror lived by humanity beginning in the 20th century, in the form of modern wars and genocides. This heritage has brought with it the exploitation of tourism in its place, and in its spaces. Battlefields, prisons, concentration camps, and other locations that were witness to cruelty and terror are now world-class tourist attractions. This, however, does not mean that all of these destinations express the value or spirit of that history in similar fashion, or even that they are classified even in theoretical terms within the same model of tourism.

It is from that very consideration that this study is born. The last two decades have given us numerous new categorizations that serve to identify and define those tourist practices related to places linked to that grim history of death and tragedy. Standing out among them due to their popularity and academic impact are the models of dark tourism and memorial tourism.

From within the confusion in the academic world of tourism regarding correct identification of either of these two models emerges the need to identify the particular defining points of each. Thus, establishing those key defining characteristics will make it possible to determine what it is that constitutes common ground between one model and the other, where confusion may exist, what elements help foster that confusion, and, above all, to solidify those attributive features that constitute clear divergences between them.

It is not difficult to comprehend how there exists certain confusion with respect to the identification of the varying typologies of tourism created by academia in order to label practices that are ostensibly similar. In addition to those already mentioned as the main focus of this paper, there are numerous other existing categories the likes of "Morbid Tourism" (Bloom, 2000), "Holocaust Tourism" (Ashworth, 1996; Beech, 2000), "Genocide Tourism" (Beech, 2009), "Prison Tourism" (Strange and Kempa, 2003), "graveyard visits" (Seaton, 2002), "Battlefield Tourism" (Smith, 1998) and others that by their very nature are birthed into existence and development by some tragic historical matter. All of them, however, are related in a greater or lesser extent to the theoretical model of dark tourism; "a travel niche developed around the historical value of sites of death and tragedy" (Mancinelli and Palou, 2016: 167) whose academic prominence and ability to embrace such heterogeneous practices cordon it as the umbrella above which all other similar typologies find shelter (Roberts and Stone, 2014). So much so, as Sharpley (2009a: 6) points out, "the meaning of the term has become increasingly diluted and fuzzy."

Memorial tourism, however, deserves to be considered outside the aforementioned umbrella which encompasses all or part of the typologies mentioned above, because it originates and develops in a completely different context - not merely and strictly academic, but now also geographic. Despite being a relatively incipient model in its academic field, there are already several important contributions that have made it a consolidated typology and reference.

Based on the considerations that can be drawn from the theoretical analysis of both models, we will be able to discern those key elements that, beyond classification itself, determine how or why one label can be used to the detriment of another and in what contexts it happens.

\section{The theory of dark tourism}

The categorization of dark tourism took hold in the mid-1990s, when Foley and Lennon (1996b: 198) defined it as "the presentation and consumption (by visitors) of real and commodified death and disaster sites." With the exception of the case of the "Black Spot" (Rojek, 1993), spaces that evoke a tragic memory with sufficient potential for attracting 
visitors, this was the first relevant academic approximation to denote what was until then a non-standard tourist practice which was beginning to garner attention for its global impact in the world of contemporary tourism, such that "several dark sites worldwide have become popular tourist attractions, drawing millions of tourists" (Farmaki, 2013: 287).

Subsequently, further contributions continued to incorporate new elements within the typification of dark tourism. Stone $(2005,2006)$ collaborated strongly in this process, stating with emphasis that "dark tourism refers to visits, intentional or otherwise, to purposeful/non-purposeful sites which offer a presentation of death or suffering as the raison d'être" (Stone, 2005: 112), or which represent the "act of travel to tourist sites associated with death, suffering or the seemingly macabre" (Stone, 2006: 146). In similar fashion, Tarlow (2005: 48) described it as those "visits to places where tragedies or historically noteworthy death has occurred and that continue to impact our lives". Lennon and Foley (2000) would take charge in strengthening the model that they themselves conceptualized just a few years earlier, in a book where they highlight diverse cases around the world, and that without a doubt is considered until today as the most cited reference worldwide on the topic (Sharpley, 2009a; Sharpley and Stone, 2009; Isaac and Ashworth, 2012). More recently, some approaches from a sociological point of view have stated that, in the context of the global capitalist system, dark tourism emerges as a practice where visitors enjoy the suffering in others (Tzanelli, 2016; Korstanje, 2016).

Developing with similar characteristics was another model parallel to the categorization of dark tourism: Thanatourism; a term coined by Seaton (1996) precisely in the same monograph where the new concept of dark tourism was presented. He defined and justified the emergence of this new academic term as such:

"Dark tourism is the travel dimension of thanatopsis which is why we shall rename it Thanatourism and define it as it follows: Thanatourism is travel wholly or partially motivated by the desire for present or symbolic encounters with death, particularly, but not exclusively, violent death, which may, to a varying degree be activated by the person-specific features of those whose deaths are their local objects" (Seaton, 1996: 240).

As Korstanje (2016) points, the term thanatopsis is a neologism first coined by William Cullen Bryant in his poem named in the same way (1817), later analyzed by Seaton as the "contemplation of death" (Seaton, 1996: 235) that has been present in mankind for centuries. Therefore, according to Seaton, the relation of thanatopsis to traveling motivated purely for the practice of such should be known as thanatourism. In any case, both terms are used in a complementary way by the academic world, with it being common to refer to oneself as a thanatourist a person who practices dark tourism, and they being considered, to a certain extent, synonymous. In this respect, Stone defines thanatourism as the "scholarly sister term" (Stone, 2013: 310) of dark tourism.

Despite being established as a new category of tourism just a few years ago, dark tourism has existed from the very moment people have travelled, being an identifiable practice throughout history (Seaton, 1996; Seaton and Lennon, 2004; Sharpley, 2009a; Stone, 2011; 2012; Roberts and Stone, 2014). There are several historical examples to which the label of dark tourism could be applied, as long as it included the expedition of those who experiment it. Although the existential reasons for travelling were clearly different, all those pilgrimages motivated for centuries by a cultured people towards deceased beings might be considered examples of this (Seaton, 1996). In the same way, very ancient forms of tourism related to death are found in gladiatorial exhibitions in Rome, public executions during medieval times, and even in guided visits to a Victorian morgue (Stone, $2005 ; 2006)$. In spite of this, Lennon and Foley (2000: 119) argue that "an event represented as dark tourism is likely to have taken place in the last hundred years", since according to its vision, those events happened before the $X X$ century cannot be catalogued as pure dark tourism because they are neither part of the memory of the living nor do they question 
contemporary morality (Lennon and Foley, 2000).

In any case, it has only been since the last half century, in obvious conjunction with the global growth of tourism in general, that dark tourism has increased considerably (Sharpley, 2009a). Without a doubt, a key element that helps us to understand said expansion is the influence of the mass media (Seaton, 1996; Lennon and Foley, 2000), Because, as Foley and Lennon (1996a: 197) point out, "where an event received attention via news and film media, the Dark Tourism would not be far off."

What is certain is that the cast of different facilities and spaces that exist within the category of dark tourism are as ample and varied as the motives behind those who partake in it (Stone, 2006; Isaac and Ashworth, 2012). Broad and plentiful are the classifications of spaces that scholars have dedicated thus far to dark tourism. Miles (2002: 1175) points out that "there is a difference between sites associated with death, disaster, and depravity and sites of death, disaster, and depravity." Taking the example of the "Washington Memorial Museum" and the "Auschwitz Memorial", it indicates that those places where the tragedy is represented without direct connection to the place where it originated can be classified as "dark", while those located in the original place of the same receive the designation of "darker" thanks to their increased component of authenticity not found in the previous ones. For Stone (2006: 145),

"dark tourism products may lie along a rather 'fluid and dynamic spectrum of intensity', whereby particular sites may be conceivably 'darker' than others, dependent upon various defining characteristics, perceptions and product traits."

He thus divides them in this manner into 7 separate categories (Stone, 2006): "Dark Fun Factories", "Dark Exhibitions", "Dark Dungeons", "Dark Resting Places", "Dark Shrines", "Dark Conflict Sites", and "Dark Camps of Genocide". Depending on factors such as the discourse, the authenticity of the site, the historical time under examination, the intentionality or the level of tourist infrastructure, establishes a spectrum of intensity that would rank the first spaces as more soft or light, while the latter would represent the harder and darker portion of dark tourism. Sharpley (2009a), on the other hand, expounds on the matrix of supply and demand, where the conjunction of its factors lead to the classification of 2 types of dark tourism: "Pale" and "Black", based on the interest of the visitor and the intent of the space being visited. It also states that the "grey tourism demand" is formed by those visitors with a high degree of motivation towards sites not arranged or organized with the intent of being "dark", and that the "grey tourism supply" consists of those spaces where death is exploited in intentional manner and are frequented by tourists whose motivation for the subject exists, but where the motivation is not determinable.

Dark tourism is without a shadow of a doubt a consolidated field of study, as evidenced by the large number of approaches made from very heterogeneous geographical realities (Biran and Hide, 2013), and likewise the great number of postgraduates in the subject matter (Stone, 2013). Despite this, and even with the increasing popularity shown in the last century, the understanding of the phenomenon still remains limited (Biran, Poria, and Oren , 2011). Perhaps the existing limitation on quantitative studies may be a hindrance towards the real understanding of the phenomenon (Coutinho and Baptista, 2014), since qualitative approaches numerically predominate (Wight, 2005; Biran and Hide, 2013).

For a better global understanding of the phenomenon, then, it seems necessary "to keep an open mind and resist the temptation to constrain it to a strict definition" (Biran and Hide, 2013: 196). The proven relevance of the subject provokes a rich and abundant conceptual debate, as Stone (2012: 1569) echoes, "there is no universal typology of dark tourism, or even a universally accepted definition".

\section{Memorial tourism: from French field to academia}

At a strictly theoretical level, the first approximation towards something known as memorial tourism happens in this reference: 
"Memorial tourism can be globally defined as a process that encourages the public to explore all the enhanced elements of heritage in order to obtain the civic and cultural enrichment provided by the reference to the past" (Cavaignac and Deperne, 2003: 14).

It is an academic definition that gives a name to a practice occurring for decades on French soil, a place where touristic exploration of its sites of memory has had enough relevance to forge its own model. The impact of "Les lieux de mémoire", the enormous reference work led by French historian Pierre Nora (1984), positions memorialization as the concept that is key for the growth and advancement of a legitimate field of study in the realm of social sciences; Memory Studies. The confluence between this impact and the strength of the tourism sector ends up forging the relationship between memory and tourism, which will lead to the creation of a theoretical corpus and the demarcation of the model known as "tourisme de mémoire".

Civic education and territorial development are the objectives of memorial tourism in France. It is a question of awakening - thanks to the use of interpretive tools of a pedagogical nature the historical conscience of the tourist so that, through recollection of the history, acknowledge and accept the past, however hard it may be (Urbain, 2003). Memorial tourism goes beyond the simple learning of a site or its historical subject; it should provoke an internal reflection upon the visitor, its consequences from that past and its implications in the present.

The first examples established as the origin of the practice of memorial tourism are found in France immediately following the First World War, when the most emblematic spaces of the many battles fought became places of pilgrimage (Da Silva and Bougon, 2013; Piernas, 2014). It was, of course, a very archaic model that has little to do with the present one, but whose evolution has been essential in respect to the existing memorial tourism of today.

The war zones are, therefore, the origin of memorial tourism. They are spaces with an extremely important burden within the demand of global tourism, since according to Smith (1998: 202), the "war-related tourism attractions are the largest single category known". The relevance of war-related sites to tourism has always been well-known throughout history, but World War I marked a before and after (Baldwin and Sharpley, 2009), becoming from that moment something massive and planned. The dramatic scale of loss of life in the Great War, unprecedented in history, was in itself instrumental in necessitating the erection of large-scale commemorations (Edwards, 2000; Roigé, 2016) and the consequent policy towards these memorials.

Although World War I can be considered as the true turning point in the boom of tourism at locations where the struggles of war once occurred, there is in fact a far earlier precedent: the Battle of Waterloo. Seaton (1996, 1999) catalogued this instance of war as the first major touristified battle in history. So touristified was this instance of conflict, that not only did the battle generate a flow of tourists after it occurred, but spectators and visitors were attracted to the combat during and even before the battle commenced. Nonetheless, it is very far from the theoretical model of memorial tourism, due not only to the precariousness of the structures dedicated to its valuation, but primarily, the development of a discourse elaborated around the exaltation of war itself and Imperialist British patriotism in the 19th century. These values are far from the civic reflection that normally uphold the practice of memorial tourism understood as such.

We find the first example of memorial tourism erected after World War I in the train journeys organized by the "Compagnie du Chemin de Fer du Nord".

"The MInistry of Public Works and Transport approves the proposal of the Company to implement, as of May 11th, 1919, on Sundays, an excursion train Paris-AlbertArras-Lens-Paris traversing the battlefields of the Somme and the Artois" (Piernas, 2014: 4).

These trips, which offered extensive services according to the class of service and whose tickets were available at a multitude of points of 
sale, do indeed fit the memorial tourism model since the intent was for them to be a source of economic revitalization for the region while exercising a function centered on social need, linked in this case with the mourning of many relatives (Piernas, 2014).

The real appreciation of touristic value in the heritage contained within French memorial tourism sites begins to take shape in the 1970 's, and later intensify and consolidate in the 1990's. Hertzog (2012: 3) outlines the process developed by the region of $\mathrm{La}$ Picardie:

"Throughout the 1980s/1990s, facing deindustrialization and the vulnerability of certain activities, the "factory" of new territorial resources relying on memory and tourism appears locally as a possible response. The category "tourisme de mémoire" is increasingly claimed by the public local stakeholders as a lever for developing and boosting territories. The expression, used in common language, is officialised by the policy of the State, which launches it as a new network by the end of the 1990s".

The case put forth by La Picardie, with the Department of the Somme as the most significant example, applies also to other neighboring regions such as Nord-Pas-deCalais or Normandie, which successfully executed the valorization of the remnants of their memorial heritage sites associated with both World Wars.

Memorial tourism already comprised of these distinctive features: transmission of civic values and territorial development. It was not only practiced by former combatants and family members, but also by a large and diversified group where the students are the majority and visitors from outside France flock to visit in consistent numbers. The generational change has undoubtedly been a key factor in this transformation. People who have not lived the conflicts in question are interested in the sites, thus creating the need to develop interpretation tools for the means of explaining, seducing and shifting the behavior of the spectator (Bouliou, 2013). Explain in order to give merit to the visit and to better understand the present time for improved preparations towards the future; Seduce in order to invoke the emotions that bring the visitor closer to the intended soul of the space itself; And modify the attitude or behavior of the spectator in order to make him a participant and actor in the visit of that space, such that he can relate the facts presented with his own life, history and values. Memorial tourism should be presented in such a way that its places can be relevant for the present (Guixé, 2008; Font, 2013). As Guixé (2008: 224) puts it, "we must avoid the monumental resources of petrification of the memorial that looks to the past, and build to establish with transparent function of ethical transmission and social pedagogy." The reflexive element around memorial tourism is very powerful, and for that reason the visitor understands its practice not from the historical point of view but from a civilian approach (Bouliou, 2013). For this reason, perhaps, the concept of memorial tourism has been increasingly imposed in France on other concepts such as battlefield tourism or historical tourism (Hertzog, 2013).

The moment from whence memorial tourism begins to receive enormous relevance and be identified as a singular and unique tourist practice, is in the year 2003, with the birth of the "chémins de mémoire" project (Cavaignac and Deperne, 2003). An offspring of the collaboration between the Ministry of Defense and the Ministry of Crafts, Trade and Tourism, a new network of sites and facilities grew which encompassed locations all across France. The DMPA ("Direction de la Mémoire, du Patrimoine et des Archives") and the ONACVG ("Office National des Anciens Combattants et Victimes de Guerre"), institutions born of defense and protagonists of the valorization process of memorial heritage sites, work side by side for the first time with tourist agents at a national level developing a genuine model of essential management. The sites of the First and Second World War, as well as those of the Holocaust, are the main protagonists of this network and, accordingly, memorial tourism in general.

In 2012, 'Atout France', the official tourism agency of France, publishes a rigorous study (Mantei, 2012) to determine the economic impact of memorial tourism within France. We 
conclude from the study that facilities attached to memorial tourism attract more than 6 million visitors annually, of which almost half are foreigners. The study, carried out during high season in 2010, includes within its study only slightly more than $20 \%$ of the country's facilities, suggesting that the percentage of international visitors should be significantly lower, and that the number of visitors from around the world notably higher. In addition to this incredibly valuable quantitative data, the study provides precise information with respect to different typologies of the memorial tourist, establishing six different groups based in function of their interest in history or memorials or their ideological motivation within the general public or in the public itself, specifically.

We have at this point identified a clear model, based on territorial development thanks to tourism and the use of interpretive tools for the dissemination of an ethical message. This does not mean, however, that the ethical message that emerges in all cases is equivalent, or even similar, or that the degree of territorial development sought is relevant in all cases. As we have seen in the original French example, the ethical and civic values of peace are a common link within the model as a whole. Other analyses of leading memorial tourism sites have been made in distinct geographical circumstances - Catalonia being the most significant. The valorization of the spaces of the Battle of Ebro must be understood, according to Andreu and Pujadas (2011), as a tool for the aim of democratic normalization of the country. Similarly, González $(2014,2016)$ states that the development of the network of memorial spaces in Catalonia and its clear tourist vocation has been one of the many memorial policies aimed at disseminating democratic memory. We see how in this case memorial tourism enhances democratic values, since the historical memory in Catalonia, as in the rest of Spain, are related with the repression and loss of liberties after the republican defeat in Spain's Civil War. Therefore, following a perspective that goes beyond the French scope, memorial tourism could be defined as a practice developed around the enhanced sites of memory, individually or as part of a comprehensive strategy, which requires the use of didactic tools in order to promote ethical values.

It is necessary to point out, lastly, a conceptual note: as an integral part of the large family of cultural tourism, memorial tourism is served by the exploitation of a cultural heritage for its development. The memorial heritage, that is, those material and immaterial vestiges related to events constitutive of collective memory that evoke individual or collective figures of the past, is the heritage exploited by memorial tourism. This can be manifest in many different forms and cases, such as natural spaces, war heritage, sanctuaries, ruins, cemeteries, mass graves, museum spaces, and so on. All of them make possible the existence of memorial tourism.

\section{Darkness vs Memory: The "dispute" over convergent places}

Many are the contributions provided by the academic world, some of them previously raised, to identify and classify the different spaces and practices within dark tourism. The range is extremely broad, encompassing an enormous number of places and experiences (Sharpley, 2009a), where one can find anything from museum representations of ancient dungeons to concentration camp memorials, to an improvised homage to some deceased celebrity. Among them, indeed, are places that have in common the practice of memorial tourism. These are places referring to some historical fact constitutive of collective memory. Battlefields, memorials, cemeteries, concentration camps, or prisons, are amongst what we will come to call as convergent spaces between dark tourism and memorial tourism. The existence of said spaces and the ambiguity with respect to its position in one model or another, raises the need to identify where its classification would be more correct or analyze why they are considered to be presently positioned in one model or the other.

Having summarized the defining characteristics of each model, it seems obvious to think that dark tourism represents a more banal and empty practice than memorial tourism, and that this could perhaps represent the main difference between the two. Certainly, dark tourism is associated in the typical tourist's imagination as a practice that trivializes 
aspects related to death, where issues related to morbidity prevail as the principal motivation (Stone, 2006; 2009), and where exists in a relatively consensual way, "the suggestion of a pejorative shade to the term 'dark tourism"' (Wight, 2009: 129). Certainly much of the blame for the existence of this perception lies with the "mass media" of the Western world, who have focused their approach to the subject largely on the moral aspects stirred up by dark tourism (Stone, 2009).

However, it is only necessary to return to the first theoretical interpretation of dark tourism to deliberate that this is an inaccurate belief. It was previously stated that the practice of dark tourism was motivated by "remembrance, education or entertainment" (Foley and Lennon, 1996a: 195). Thus, those visits motivated by mere entertainment, and therefore clearly susceptible to the possible motivation of simple trivialization of the site, would be only a small part of the overall list of motivations of the "dark tourist". The educational dimension is clearly present and helps to distinguish between the profound experiences capable in dark tourism to those more superficial ones (Cohen, 2011), although the pedagogical nature of the message of a dark site and its value within tourism is something that is in many cases, quite confused (Stone and Sharpley, 2008).

Having observed the likely concurrence of both theoretical models converging on the same tourist sites, it is, notwithstanding, unmistakably clear that not all tourists who visit "dark sites" are "dark tourists" (Slade, 2003; Baldwin and Sharpley, 2009; Biran, Poria, and Oren, 2011; Isaac and Ashworth, 2012). In the same way, many of the tourists who visit these convergent spaces would be horrified to be classified in the same group as those who visit more superficial sites equally categorized as dark (Stone, 2006; Baldwin and Sharpley 2009; Roberts and Stone, 2014). As Biran and Hide point out (2013: 192):

"a supply-side approach raises questions regarding whether it is justifiable to categorize collectively experiences at theme parks such as the London Dungeon alongside the experiences of visitors to genocide camps, as dark tourism, and whether the concept of dark tourism is helpful at all for tourism research".

This leads us to argue that the principal difference between dark tourism and memorial tourism is precisely that, as it has been previously mentioned, memorial tourism is a concept that was born vis-à-vis the action of tourist agents, first at the local level and later at a national level within France, so that, now at once a consolidated brand, it becomes its own distinct type of tourism analyzed by scholars. On the contrary, dark tourism is born from the academic and for the academic, being most prevalent in the Anglo-Saxon and Asian areas. Labels like dark tourism or thanatourism are conjured up within an office inside university walls to define something that is already a reality in the tourist world. Such labels, moreover, "seem to exist without the consent or collaboration of the tourism sector" (Wight, 2009: 129).

This forked view between supply-demand and the role of the academic helps to process the notion that it is practically impossible to find tourist facilities or places that might be reclaimed as dark tourism - something diametrically opposite when considering the same in memorial tourism. Likewise, an analytical perspective filtered in geographical perspective, which clearly places memorial tourism rather squarely in the context of the French-speaking world, solidifies the fact that the theoretical contributions to memorial tourism from the Anglo-Saxon academia are, thus far, just a few. It is the French academia itself, and as a result of its roots of influence the Hispanic academia as well, who has heretofore carried out perhaps the entirety of the theoretical study on memorial tourism. Conversely, the contributions made from Hispanic academia to the theoretical development of "dark tourism" are really quite scarce. The only outstanding contribution comes from Korstanje. On the one hand, he has noted that, despite the global relevance and recurrence of dark tourism studies, they only have academic predominance in the United Kingdom (Korstanje, 2014, 2015, 2016). On the other hand, he has analyzed, from an anthropological perspective, the role of dark tourism in changing the social function of death 
(Korstanje, 2014, 2015), and its 'cohesion' value in a social order shaken by some tragic or traumatic event (Korstanje and Ivanov, 2012).

The clear identification of memorial tourism with France, like the involvement of agents from the supply side, has made possible a quantitative approach as rigorous as that accomplished in "Atout France" (Mantei, 2012). In it, light is shone on all the elements involved in memorial tourism, facilitating a comprehensive understanding of the phenomenon and subsequent academic work. Dark tourism, however, has no clear attachable geographic classification. Because of the difficulties ramified by its own obscurity and the ongoing divorce between scholars and agents of supply, theoretical approaches do not go beyond the qualitative field, and consequently the studies of dark tourism suffer from a certain degree of inexactness and inconclusiveness.

At a purely conceptual level, it can be said that death is the principal object in the analysis of dark tourism, with memorialization being somewhat secondary. By contrast, in memorial tourism it is the memorialization itself that plays the leading role, with death being only a complementary element to take into account from a sociological perspective. Dark tourism represents an individual focus on death (Stone and Sharpley, 2008; Stone, 2012), while memorial tourism addresses the approximation to death in a global fashion as part of a system of creation and implementation of collective memory. Linked to this point, we find that memorial tourism has a clear heritage reference for its study in cultural tourism. Memorial heritage and the sites of memory represent this reference that facilitates its theoretical analysis. Dark tourism, whose spectrum is broader since death participates in numerous processes of heritage education and development, does not have such a clear reference, and so the "dissonant heritage" (Ashworth and Tunbridge, 1996), with all its complications and analytical limitations, becomes the closest thing to it (Figure 1).

\section{Conclusions}

Academic studies on tourism, which enjoy an enviable health as evidenced by the great amount of scientific production on the matter, have provided then a great variety of theoretical models that identify the many types of tourism that exist today. Heritage sites

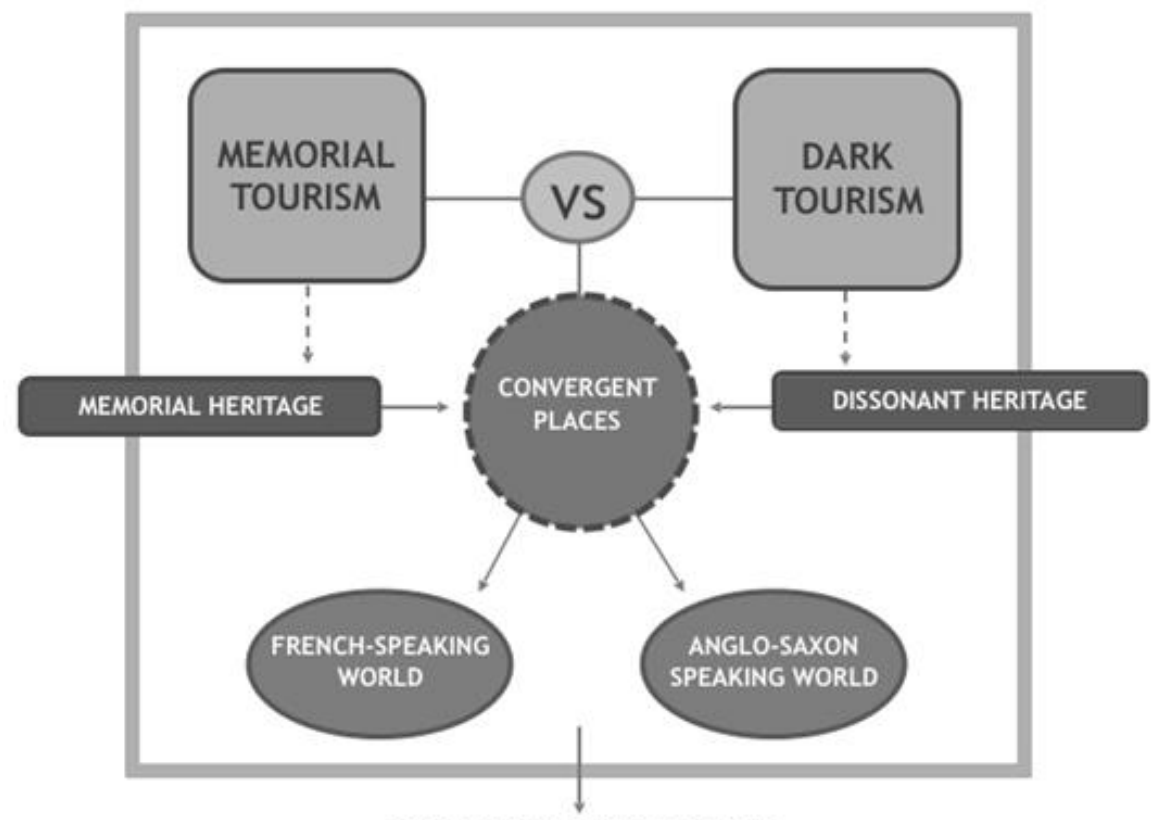

CULTURAL TOURISM

Figure 1. Diagram of convergent places 
related to tragic events have become in the last decades genuine world-class tourist resources, a fact that has led them to be analyzed at the theoretical level and, consequently, to be categorized in scrutiny under one of the many models typified by the academics. Thus, both dark tourism and memorial tourism have become theoretical reference models for the analysis of tourism practices in those heritage sites related to their respective tragedy, which we have termed as convergent places due to their arguable fit within either model. In talking about models with similar characteristics, and having a remarkable degree of acceptance at not only an academic level but also at a visible level within the mass media, it is unsurprising that there is some confusion in establishing what tourist practices are solely part of one model, or the other.

Certain peripheral approaches may suffer from a simplistic view that places dark tourism within the framework of a tourist practice exclusively related to its morbidity, just as memorial tourism is related to a model of transmission of ethical values. The latter position having been found to be proven correct, it is not less true to say that whom finally gives meaning to a tourist visit is the primary protagonist, that is to say, the very tourists themselves. Therefore, the border between that which is morbid and that which is pedagogical transcends beyond any academic labels qualitative in nature, and it is the tourist's definition which holds.

But beyond certain conceptual details, the obvious and certain is that any tourist place that can be tagged as residing within one model can also be tagged in another, or several at a time. What is interesting, then, is not the debate over what term would be the most appropriate to use to define according to the place, but to identify why that tourist place is classified in one model or another.

Thus, we see how dark tourism was born in the academic field as a term strictly of academic use, while the "tourisme de mémoire" began to be used as a brand developed by the tourism agents themselves, later to be adopted by academia as a theoretical model. For that reason, it is highly improbable to find cases in which from the supply itself, the offer, the site identifies itself as dark tourism and if one were to identify with either label, evidently, that they should do it under the umbrella of memorial tourism.

We also see how the geographical framework is significant, dark tourism developing in the Anglo-Saxon and the Asian world and memorial tourism in the French-speaking world and, later, in the Hispanic-speaking world. Such is the reason why there are so few important contributions from the Hispanic academia on the study of dark tourism, as the attempts of the Anglo-Saxon academics are very few towards memorial tourism either. The convergent places will be analyzed as part of one model or another largely due to the influence of the geographical scope where such analysis is undertaken.

Dark tourism and memorial tourism are only two labels, two designations that define a determinate typology of tourism. The contributions derived from the present study establish a basic comparative framework that helps corroborate in ending a certain degree of confusion between the two terms. Future contributions should continue to implement new forms of analysis to determine the extent to which a tourist practices dark tourism or memorial tourism over convergent spaces.

\section{References}

Andreu, A., and Pujadas, J.J. (2011). El turismo de memoria: la patrimonialización de la memoria histórica en Catalunya. El proyecto "Más allá de una batalla" (la batalla del Ebro, Gandesa). In Prats, LI. and Santana, A. (Coords.) (2011). Turismo y patrimonio, entramados narrativos. La Laguna (Tenerife): Pasos Edita, 271. 287.

Ashworth, G. (1996). Holocaust Tourism and Jewish Culture: the lessons of KrakowKazimierz. In Robinson, M., Evans, N., and Callaghan, P. (Eds.) (1996). Tourism and cultural change. Sunderland: Business Education Publishers, 1-12.

Ashworth, G. (2002). Holocaust Tourism: the experience of Krakow-Kazimierz. International Research in Geographical and Environmental Education, 11 (4), 363367. 
Ashworth, G., and Turnbridge, J. (1996). Dissonant Heritage: The management of the past as a resource in conflict. New York: Wiley.

Baldwin, F., and Sharpley, R. (2009). Battlefield Tourism: Bringing Organised Violence Back to Life. In Sharpley, R. and Stone, P. (Eds.) (2009). The Darker Side of Travel. The Theory and Practice of Dark Tourism. Bristol: Channel View Publications, 186206.

Beech, J. (2000). The Enigma of Holocaust Sites as Tourist Attractions - The case of Buchenwald. Managing Leisure, 5, 29-41.

Beech, J. (2009). Genocide Tourism. In Sharpley, R. and Stone, P. (Eds.) (2009). The Darker Side of Travel. The Theory and Practice of Dark Tourism. Bristol: Channel View Publications, 207-223.

Biran, A., and Hyde, K.F. (2013). New perspectives on dark tourism. International Journal of Culture, Tourism and Hospitality Research, 7 (3), 191-198.

Biran, A., Poria, Y., Oren, G. (2011). Sought experiences at (dark) heritage sites. Annals of tourism Research, 38 (3), 820841.

Blom, T. (2000). Morbid Tourism: A Postmodern Market Niche with an Example from Althorpe. Norwegian Journal of Geography, 54, 29-36.

Bouliou, C. (2013). Du tourisme des batailles au tourisme des mémoires. Cahier Espaces, 313, 68-71.

Bryant, W.C., and Wilson, W. (1817). Thanatopsis. New York: GP Putnam's Sons.

Cavaignac, F., and Deperne, H. (2003). Les Chemins de mémoire. Une initiative de l'État. Cahier Espaces, 80, 12-21.

Cohen, E.H. (2011). Educational Dark Tourism at an In Popolo Site: the Holocaust Museum in Jerusalem. Annals of tourism Research, 38 (1), 193-209.

Coutinho, B., and Baptista, M. (2014). Espaços dentro de sítios e sítios dentro de espaços: o turismo negro como mediador da morte ausente/presente. In Araujo, E., Duque, E., Franch, M., and Durán, J. (Eds.) (2014). Tempos Sociais e o Mundo Contemporâneo - As crises, As Fases e As Ruturas. Braga: Centro de Estudos de Comunicaçao e Sociedade-Universidade do Minho, 55-67.
Da Silva, M., and Bougon, L. (2013). Le tourisme de mémoire. Un enjeu cívique, pédagogique, économique et culturel pour la France. Cahier Espaces, 313, 48-51.

Edwards, P. (2000). Mort pour la France: Conflict and commemoration in France after the First World War. University of Sussex Journal of Contemporary History, 1, 1-11.

Farmaki, A. (2013). Dark Tourism revisited: a supply/demand conceptualization. International Journal of Culture, Tourism and Hospitality Research, 7 (3), 281-292.

Foley, M., and Lennon, J. (1996a). Editorial: Heart of Darkness. International Journal of Heritage Studies, 2 (4), 195-197.

Foley, M., and Lennon, J. (1996b). JFK and Dark Tourism: a fascination with assassination. International Journal of Heritage Studies, 2 (4), 198-211.

Font, J. (2013). Un equipament amb vocació transfronterera: el Museu Memorial de I'Exili de la Jonquera (MUME). In Camiade, M. (Dir.) (2013). Euroinstitut Català Transfronterer. Recull de conferències 2010-2012. Perpignan: Balzac Editeur, 23-38.

González, D. (2014). La práctica turística como mecanismo de transmisión de valores: Cataluña y los lugares de memoria democrática. Revista Iberoamericana de turismo - RITUR, 4 (especial), 36-49.

González, D. (2016). La patrimonialización de la memoria histórica: entre el deber social y la estrategia turística. Apuntes sobre el caso catalán. PASOS - Revista de Patrimonio y Turismo Cultural, 14 (5), 1267-1280.

González, D. (2017). El turismo de memoria y las implicaciones de la frontera: una aproximación teórica desde los Pirineos. In Arnabat, R. and Duch, M. (Eds.) (2017). Polítiques memorials, fronteres $i$ turisme de memòria. Perpinyà - Tarragona: PUP/URV publicacions, 97-114.

Guixé, J. (2008). El Memorial Democrático y los lugares de la memoria: la recuperación del patrimonio memorial en Cataluña. Entelequia, 7, 217-228.

Guixé, J. (2017). Espais i models sobre la memòria històrica, Usos públics i patrimonials. In Arnabat, R. and Duch, M. (Eds.) (2017). Polítiques memorials, 
fronteres i turisme de memòria. Perpinyà Tarragona: PUP/URV publicacions, 25-45. Henderson, J. (2000). War as a tourist attraction: The case of Vietnam. International Journal of Tourism research, 2, 269-280.

Hertzog, A. (2012). Tourisme de mémoire et imaginaire touristique des champs de bataille.VVia@, Les imaginaires touristiques, $1 . \quad$ URL : https://journals.openedition.org/viatourism/ 1276 (Accessed on 08.06.2018).

Hertzog, A. (2013). Quand le tourisme de mémoire bouleverse le travail de mémoire. Cahier Espaces, 313, 52-61.

Isaac, R.K., and Ashworth, G. (2012). Moving from pilgrimage to "Dark" Tourism: Leveraging tourism in Palestine. Tourism, Culture and Communication, 11, 149-164.

Korstanje, M. (2014). Puntos esenciales del turismo oscuro, un debate conceptual. Gran tour: Revista de investigaciones Turísticas, 10, 23-35.

Korstanje, M. (2015). The Anthropology of Dark Tourism, Exploring the contradiction of Capitalism. CERS Centre for Ethnicity and Racism Study. University of Leeds UK. Working paper $22 . \quad$ URL: https://cers.leeds.ac.uk/wpcontent/uploads /sites/97/2015/02/Korstanje_CERS_15.pdf (Accessed on 08.06.2018)

Korstanje, M. (2016). The rise of Thana Capitalism and Tourism. London: Routledge.

Korstanje, M., and Ivanov, S. (2012). Tourism as a form of new psychological resilience: the inception of Dark Tourism. CulturRevista de cultura e turismo, 6 (4), 56-71.

Lennon, J., and Foley, M. (2000). Dark tourism: the attraction of death and disaster. London - New York: Continuum.

Mancinelli, F., and Palou, S. (2016). Editorial Tourism and the place of memory. International Journal of Tourism Anthropology, 5 (3/4), 165-171.

Mantei, C. (Dir.) (2012). Le tourisme de mémoire en France: mesure et analyse du poids et des retombées économiques et de la filière. Paris: Atout France.

Miles, W. (2002). Auschwitz: Museum interpretation and Darker Tourism. Annals of Tourism Research, 29 (4), 1175-1178.
Nora, P. (Dir.) (1984). Les Lieux de mémoire. Paris, Gallimard.

Piernas, G. (2014). Les pèlerinages dans les régions dévastées du nord de la France organisés par la Compagnie du chemin de fer du Nord au lendemain de la Première Guerre mondiale. In Situ, 25. URL: https://journals.openedition.org/insitu/1142 0 (Accessed on 08.06.2018).

Roberts, C., and Stone, P. (2014). Dark Tourism and Dark Heritage: Emergent Themes, Issues and Consequences. In Convery, I., Corsane, G., and Davids, P. (Eds.) (2014). Displaced Heritage. Responses to disaster, trauma, and loss. Newcastle: The Interpretation Centre for Cultural and Heritage Studies (Newcastle University), 9-18.

Roigé, X. (2016). De monumentos de piedra a patrimonio inmaterial. Estrategias políticas, museológicas y museográficas de presentación de la memoria. In Arrieta, I. (Ed.) Lugares de memoria traumática. Representaciones museográficas de conflictos políticos y armados. Bilbao: UPV/EHU Servicio Editorial, 23-47.

Rojek, C. (1993). Ways of Escape. Basingtoke: Macmillan.

Seaton, A.V. (1996). Guided by the dark: from thanatopsis to thanatourism. International Journal of Heritage Studies, 2 (4), 234244.

Seaton, A.V. (1999). War and Thanatourism: Waterloo 1815-1914. Annals of Tourism Research, 26 (1), 130-158.

Seaton, A.V. (2002). Thanatourism's final frontiers? Visits to cemeteries, churchyards and funerary sites as sacred and secular pilgrimage. Tourism Recreation Research, 27 (2), 73-82.

Seaton, A.V., and Lennon, J. (2004). Moral panics, ulterior motives and alterior desires: Thanatourism in the early $21 \mathrm{st}$ century. In Singh, T. (Ed.) (2004). New Horizons in Tourism: Strange Experiences and Stranger Practices. Wallingford: $\mathrm{CABI}$ Publishing, 63-82.

Sharpley, R. (2009a). Shedding Light on Dark Tourism: An Introduction. In Sharpley, R. and Stone, P. (Eds.) (2009). The Darker Side of Travel. The Theory and Practice of Dark Tourism. Bristol: Channel View Publications, 3-22. 
Sharpley, R. (2009b). Dark Tourism and Political Ideology: Towards a Governance Model. In Sharpley, R. and Stone, P. (Eds.) (2009). The Darker Side of Travel. The Theory and Practice of Dark Tourism. Bristol: Channel View Publications, 145163.

Sharpley, R., Stone, P. (2009). Life, Death and Dark Tourism: Future Research Directions and Concluding Comments. In Sharpley, R. and Stone, P. (Eds.) (2009). The Darker Side of Travel. The Theory and Practice of Dark Tourism. Bristol: Channel View Publications, 247-251.

Slade, P. (2003). Gallipoli Thanatourism: The meaning of ANZAC. Annals of tourism research, 30 (4), 779-794.

Smith, V. (1998). War and Tourism - An American ethnography. Annals of Tourism Research, 25 (1), 202-227.

Stone, P. (2005). Dark Tourism Consumption A call for research. E-Review of Tourism Research (eRTR), 3 (5), 109-117.

Stone, P. (2006). A dark tourism spectrum: Towards a typology of death and macabre related tourist sites, attractions and exhibitions. Tourism: an Interdisciplinary International Journal, 52 (2), 145-160.

Stone, P., and Sharpley, R. (2008). Consuming Dark Tourism: A Thanatological Perspective. Annals of Tourism Research, 35 (2), 574-595.

Stone, P. (2009). Dark Tourism: Morality and New Moral Spaces. In Sharpley, R. and Stone, P. (Eds.) (2009). The Darker Side of Travel. The Theory and Practice of Dark Tourism. Bristol: Channel View Publications, 56-72.
Stone, P. (2011). Dark tourism: towards a new post-disciplinary research agenda. International Journal of Tourism Anthropology, 1 (3/4), 318-332.

Stone, P. (2012). Dark Tourism and Significant Other Death. Towards a model of mortality mediation. Annals of Tourism Research, 39 (3), 1565-1587.

Stone, P. (2013). Dark Tourism Scholarship: a critical review. International Journal of Culture, Tourism and Hospitality Research, 7 (3), 307-318.

Strange, C., and Kempa, M. (2003). Shades of Dark Tourism: Alcatraz and Robben Island. Annals of Tourism Research, 30, 386-403.

Tarlow, P. (2005). Dark Tourism: the appealing "dark" side of tourism and more. In Novelli, M. (Ed.) (2005). Niche Tourism: Contemporary Issues, Trends and Cases. Oxford: Elsevier. 47-57.

Tzanelli, R (2016). Thanatourism and Cinematic Representations of Risk: Screening the End of Tourism. Abingdon New York: Routledge.

Urbain, J-D. (2003). Tourisme de mémoire. Un travail de deuil positif. Cahier Espaces, 80, 5-7.

Wight, C. (2005). Philosophical and Methodological Praxes in Dark Tourism: Controversy, Contention and the Evolving Paradigm. Journal of Vacation Marketing, 12, 119-129.

Wight, C. (2009). Contested National Tragedies: An Ethical Dimension. In Sharpley, R. and Stone, P. (Eds.). The Darker Side of Travel. The Theory and Practice of Dark Tourism. Bristol: Channel View Publications, 129-144. 